\title{
Evaluation of Different Grade NPS Fertilizers on Agronomic Performance of Faba Bean (Vicia faba L.) in Nitisol of Central Ethiopian Highland
}

\author{
Matias Dejene, Girma Chala, Zeleke Obsa and Mihretu Bedasa
}

\begin{abstract}
Field experiment was conducted to evaluate the response of different grade NPS fertilizer and their rate on the growth performance of faba bean in the central highlands of Ethiopia, Oromia regional state at Welmera and Ejere districts Nitisols by using completely randomized block design with three replication which includes two different new NPS grade fertilizers with three application rates (80, 100 and 120\%) from recommended rate with two standard and negative controls for two successive coping seasons. Where all soil, plant growth performance and yield data were collected accordingly the highest grain yield result was obtained from $80 \%$ of recommended rate of $\mathrm{P}$ from $13.3 \mathrm{~N}-36 \mathrm{P}_{2} \mathrm{O}_{5}-13.7 \mathrm{~S}$ followed by the $3^{\text {rd }}$ treatment $100 \%$ of rec. rate of $\mathrm{P}$ from $19 \mathrm{~N}-38 \mathrm{P}_{2} \mathrm{O}_{5}-7 \mathrm{~S}$ (Positive control 2). The partial budget analysis results also indicated that use of $80 \%$ of recommended rate of $\mathrm{P}$ from $13.3 \mathrm{~N}-36 \mathrm{P}_{2} \mathrm{O}_{5}-13.7 \mathrm{~S}$ grade fertilizer got highest net benefit economic advantage and marginal rate of return over other treatment followed by treatment three in both parameters.
\end{abstract}

Keywords: Nitisol, Faba bean, Different grade, NPS, fertilizer, yield and Net benefit.

DOI: $10.7176 / \mathrm{JNSR} / 12-19-02$

Publication date:October $31^{\text {st }} 2021$

\section{Introduction}

Rapid declines in soil fertility are associated with huge demands for food due to increasing population, extensive nutrient mining of agricultural areas with allied shifts of produce to cities, and intensification of agricultural activities without proper regard for long-term maintenance of fertility by application of appropriate fertilizers, recycling of organic wastes, liming to combat acidification, fallowing, rotations and prevention of large scale soil erosion aggravates the issue of sub-Saharan African countries malnutrition, these declining soil fertility is among the most constraining factor challenging food production and hence food self-sufficiency in Ethiopia (Gete et al., 2010). Application of balanced nutrition is the key role in enhancing nutrient use efficiency of applied nutrients for maintaining soil productivity and production. For the past several decades, farmers in Ethiopia used limited types of nutrients ( $\mathrm{N}$ and $\mathrm{P}$ ) in the form of urea and DAP to increase crop production. However, recently acquired soil inventory data revealed that the deficiencies of other nutrients such as sulphur, boron and zinc (on about 92, 65, $53 \%$ of the studied areas, respectively) is widespread in Ethiopian soils in addition to $\mathrm{N}$ and $\mathrm{P}$ nutrient deficiencies (EthioSIS, 2014). To alleviate the problems in this regard, the Ethiopian Soil Information System (EthioSIS), introduced different formula of blended fertilizers for evaluation in the production system of the country.

Since 2009, the country has been testing different types of new fertilizer products including blend fertilizers for their potential to improve yield and quality for food and nutrition security. as a major source of protein faba bean ensuring nutritional security and income for farming families in the highlands of Ethiopia, which have important role in enriching the soil fertility by fixing atmospheric nitrogen. It is a crop that makes significant contribution to an integrated management of soil fertility and sustainable farming systems. It stands first in area coverage as well as total production of pulse crops produced in Ethiopia (CSA, 2020). Thus, this study was initiated to evaluate faba bean response to application of different grade NPS fertilizer products in combination with Urea in their Welmera and Ejere districts of the central Ethiopian highlands.

Objectives:

- To evaluate the effect of different grade NPS blended fertilizers on yield and quality improvement of faba bean crop on Nitisol of central Ethiopia.

- To determine economically feasible optimal rate of the different grade NPS fertilizer in improving yield of faba bean production.

\section{Materials and Methods}

\subsection{Description of the Study Area}

This field trial was conducted in Welmera and Ejere districts farmers field which are located in the central highlands of Ethiopia at DMS latitude $9^{0} 03^{\prime} 32^{\prime}$ ' $\mathrm{N}$, longitude $38^{0} 25^{\prime} 62^{\prime \prime} \mathrm{E}$, Alt 2438 masl for Welmera district and at latitude of $9^{0} 02^{\prime} 76^{\prime}$ 'N Longitude $38^{0} 25^{\prime} 56^{\prime}$ 'E, Alt 2258 masl for Ejere districts specifically known Sademo and Chiri PA respectively (Table 1) they have Clay soil textural class with Nitisol genetic classification. The experiments were carried out on farmers' fields and research stations for two consecutive cropping seasons 
during 2019 and 2020 in different parts of the country during the main rainy seasons. The study locations are among major areas for the production of the test crops.

Table 1. Geographic, soil and climate information for the study site of response of faba bean to different grade NPS fertilizer trial.

\begin{tabular}{|l|c|c|c|c|c|c|}
\hline Locations & Latitude & Longitude & Altitude & $\begin{array}{c}\text { Annual total } \\
\text { rainfall }(\mathrm{mm})\end{array}$ & $\begin{array}{c}\text { Annual average min. } \\
\text { and max. temp. }\left({ }^{\circ} \mathrm{C}\right)\end{array}$ & $\begin{array}{c}\text { Soil textural } \\
\text { class }\end{array}$ \\
\hline $\begin{array}{l}\text { Wolmera } \\
\text { (Sademo) }\end{array}$ & $9^{0} 03^{\prime} 32^{\prime}{ }^{\prime} \mathrm{N}$ & $38^{0} 25^{\prime} 62^{\prime}, \mathrm{E}$ & $2438 \mathrm{~m}$ & 1100 & $6.9^{\circ} \mathrm{C}$ and $23.2^{\circ} \mathrm{C}$ & Clay \\
\hline Ejere (Chiri) & $\begin{array}{c}9^{0} \\
02^{\prime} 76^{\prime}, \mathrm{N}\end{array}$ & $38^{0} 25^{\prime} 56^{\prime} \mathrm{E} \mathrm{E}$ & $2258 \mathrm{~m}$ & 1040 & $6.70 \mathrm{C}$ and $22.90 \mathrm{C}$ & Clay \\
\hline
\end{tabular}

Moti improved faba bean variety was used as test crop for this experiment with planting space of $40 \mathrm{~cm}$ and $10 \mathrm{~cm}$ between rows and plant respectively.

\subsection{Treatments and Experimental Design}

Nine treatments consisting of negative control, positive controls and different rates of different grade NPS fertilizers (Table 2) were evaluated. For the recommended NP (positive controls), DAP and NPS $\left(19 \mathrm{~N}_{-} 38 \mathrm{P}_{2} \mathrm{O}_{5^{-}}\right.$ $7 \mathrm{~S}$ ) were used as $\mathrm{P}$ sources. The treatments were arranged in randomized completed block design (RCBD) and were replicated three times at each location. Nutrient composition of the different NPS grade fertilizers and the total amount of each nutrient applied per hectare for each treatment is indicated in Table 2. All NPS fertilizers treatment were applied at planting with band application the amount of urea or N applied with NPS fertilizers were sufficient to full fill its requirement for most treatments with few exceptions. The small amount of $\mathrm{N}$ remaining to full fill the faba bean $\mathrm{N}$ requirement was applied from Urea fertilizer at planting. The seed rate used for faba bean, was $175 \mathrm{~kg} \mathrm{ha}^{-1}$, was used for faba bean. The plot size used was $4 \mathrm{~m} \mathrm{x} 3 \mathrm{~m}$ or $12 \mathrm{~m}^{2}$ plot area. All other agronomic and crop management practices were applied as per the recommendation of the faba bean.

Table 2. Treatments setup of different grade NPS fertilizer and total amount of each nutrient applied $\left(\mathrm{kg} . \mathrm{ha}^{-1}\right)$ for faba bean.

\begin{tabular}{|c|c|c|c|c|}
\hline No. & Treatments & $\mathbf{N}$ & $\mathbf{P}_{2} \mathbf{O}_{5}$ & $\mathbf{S}$ \\
\hline T1 & Control (no fertilizer) & 0 & 0 & 0 \\
\hline $\mathrm{T} 2$ & $100 \%$ recommended rate of $\mathrm{P}$ from DAP (positive control 1) & 18 & 46 & 0 \\
\hline $\mathrm{T} 3$ & $100 \%$ recommended rate of $\mathrm{P}$ from $19 \mathrm{~N}-38 \mathrm{P}_{2} \mathrm{O}_{5}-7 \mathrm{~S}$ (positive control 2 ) & 18 & 46 & 8.47 \\
\hline $\mathrm{T} 4$ & $80 \%$ recommended rate of $\mathrm{P}$ from $12 \mathrm{~N}-42 \mathrm{P}_{2} \mathrm{O}_{5}-10 \mathrm{~S}$ & 18 & 36.8 & 8.76 \\
\hline T5 & $100 \%$ recommended rate of $\mathrm{P}$ from $12 \mathrm{~N}-42 \mathrm{P}_{2} \mathrm{O}_{5}-10 \mathrm{~S}$ & 18 & 46 & 10.95 \\
\hline T6 & $120 \%$ recommended rate of $\mathrm{P}$ from $12 \mathrm{~N}-42 \mathrm{P}_{2} \mathrm{O}_{5}-10 \mathrm{~S}$ & 18 & 55.2 & 13.14 \\
\hline $\mathrm{T} 7$ & $80 \%$ recommended rate of $\mathrm{P}$ from $13.3 \mathrm{~N}-36 \mathrm{P}_{2} \mathrm{O}_{5}-13.7 \mathrm{~S}$ & 18 & 36.8 & 14.0 \\
\hline $\mathrm{T} 8$ & $100 \%$ recommended rate of $\mathrm{P}$ from $13.3 \mathrm{~N}-36 \mathrm{P}_{2} \mathrm{O}_{5}-13.7 \mathrm{~S}$ & 18 & 46 & 17.5 \\
\hline T9 & $120 \%$ recommended rate of $\mathrm{P}$ from $13.3 \mathrm{~N}-36 \mathrm{P}_{2} \mathrm{O}_{5}-13.7 \mathrm{~S}$ & 18 & 55.2 & 21.0 \\
\hline
\end{tabular}

The recommended rate of $\mathrm{P}_{2} \mathrm{O}_{5}$ were $46 \mathrm{~kg} \mathrm{ha}^{-1}$ for faba bean, Nitrogen $(\mathrm{N})$ was uniformly applied at the rate of $18 \mathrm{~kg} \mathrm{ha}^{-1}$, except for the negative control.

\subsection{Data collection}

\section{Soil sampling and analysis}

Composite surface soil samples $(0-20 \mathrm{~cm})$ were collected from the experimental sites before treatment application as well as after harvesting to see the initial soil physicochemical properties and treatment effect on some selected soil chemical properties. The soil samples were air dried and ground by using mortar and pestle to pass $2 \mathrm{~mm}$ sieve. Soil texture, soil $\mathrm{pH}$, exchangeable acidity, organic carbon, total $\mathrm{N}$, available $\mathrm{P}$ and sulphur were determined at respective agricultural research soil Laboratories following standard lab procedures.

The determination of soil particle size distribution was carried out using the hydrometer method (Dewis and Freitas, 1984). Soil $\mathrm{pH}$ was measured using digital $\mathrm{pH}$ meter in 1:2.5 soil to solution ratio with $\mathrm{H}_{2} \mathrm{O}$ (Mclean, 1982), The exchangeable acidity was determined by extracting the soil samples with $\mathrm{M} \mathrm{KCl}$ solution and titrating with sodium hydroxide as described by McLean (1965). The organic carbon was determined following wet digestion methods as described by Walkley (1947) and Nelson and Sommers (1982) whereas the Kjeldahl procedure was used for the determination of total $\mathrm{N}$ as described by Bremner and Mulvaney (1982). The available P was determined by Bray II method (Bray and Kurtz, 1945). Available Sulfur was determined by using Turbidimetric method (Chesnin and Yien, 1951). Accordingly, the soil analysis result taken before planting at each experimental site indicated that the value of $\mathrm{pH}$, Exchangeable acidity, available phosphorus, total nitrogen, organic carbon and available Sulfur (Table 3).

Plant height, dry biomass and grain yield of faba bean and thousand seed weight was also collected following the standard procedures. 
The soil $\mathrm{pH}$ was categorized as moderately acid for all of the experimental sites according to Tekalegn, (1991) ratings. The organic carbon contents were low for all experimental sites (Table 3). The total $\mathrm{N}$ was found in the medium rating range except for HARC on station and Ejere where it was in the high rating range (Tekalign, 1991). The available phosphorus of the experimental sites was found in the low rating (Tekalign, 1991); and hence positive responses was expected from different rates of phosphorus application. According to EthioSIS, (2014) of soil sulphurs rating the values observed in this study lies in the low range of ratings.

Table 3. Mean values of soil chemical properties sampled from the experimental sites before treatment application.

\begin{tabular}{|l|l|l|l|l|}
\hline \multirow{2}{*}{ Soil parameters } & \multicolumn{3}{|c|}{ Locations } & \multirow{2}{*}{ Rating } \\
\cline { 2 - 4 } & HARC & Welmera & Ejere & \\
\hline pH (1:2.5 soil: $\left.\mathrm{H}_{2} \mathrm{O}\right)$ & 5.62 & 5.47 & 5.74 & Moderately acid (Tekalign, 1991) \\
\hline Exchangeable acidity & 0.863 & 0.927 & 0.765 & \\
\hline OC $(\%)$ & 1.36 & 1.34 & 1.42 & Low to moderate (Tekalign, 1991) \\
\hline Total N (\%) & 0.16 & 0.24 & 0.23 & Low to Moderate (Tekalign, 1991) \\
\hline Available P (ppm) & 11.68 & 9.68 & 10.42 & Moderate (Tekalign, 1991) \\
\hline Available S (unit) & 2.38 & 2.36 & 2.44 & Low (EthioSIS, 2014) \\
\hline
\end{tabular}

HARC $=$ Holeta Agricultural Research Center

\subsection{Data Analysis}

The collected plant height, dry biomass and grain yield for all the test crops and thousand seed weight were subjected to analysis of variance using SAS software version 9.2 (SAS, 2012) The dependent variables were subjected to mean separation using LSD (least significant difference) procedure when differences were found statistically significant. Partial budget analysis for yields was computed using CIMMYT procedure to determine economically profitable rates of different grade NPS fertilizers (CIMMYT, 1988). The prices of NPS, DAP and Urea were ETB 16, 16 and $14 \mathrm{~kg}^{-1}$, respectively. The grain prices of wheat and rape seed were ETB 22 and 35 $\mathrm{kg}^{-1}$. The average grain yields were adjusted down by $10 \%$ to reflect the real farmer's condition.

\section{Result and Discussion}

\section{Postharvest soil data}

The postharvest soil analysis result of organic carbon, total nitrogen and available phosphorus content for the experimental locations are indicated (Table 4 and 5). There were some differences in the analysis results of the soil parameters among the treatments including for different grade NPS fertilizer rates. However, the differences found were inconsistent and cannot be attributable to the different level of phosphorus and sulphur nutrient variations regardless of the differences in experimental location.

Table 4. After harvest soil chemical properties as affected by different grade NPS fertilizer rates for both crops at Welmera, HARC and Ejere

\begin{tabular}{|c|c|c|c|c|c|c|c|c|c|c|}
\hline \multirow[t]{2}{*}{ Treatments } & \multicolumn{2}{|c|}{$\mathrm{pH}$} & \multicolumn{2}{|c|}{$\begin{array}{c}\text { Organic } \\
\text { Carbon }(\%)\end{array}$} & \multicolumn{2}{|c|}{$\begin{array}{c}\text { Total } \\
\text { Nitrogen }(\%)\end{array}$} & \multicolumn{2}{|c|}{ Available P (ppm) } & \multicolumn{2}{|c|}{$\begin{array}{c}\text { Available } S \\
\text { (ppm) }\end{array}$} \\
\hline & 2019 & 2020 & 2019 & 2020 & 2019 & 2020 & 2019 & 2020 & 2019 & 2020 \\
\hline $\mathrm{T} 1$ & 5.52 & 5.34 & 1.38 & 1.34 & 0.18 & 0.16 & 9.92 & 10.62 & 2.32 & 2.28 \\
\hline $\mathrm{T} 2$ & 5.47 & 5.25 & 1.34 & 1.32 & 0.19 & 0.18 & 11. 48 & 10.12 & 2.34 & 2.25 \\
\hline T3 & 5.26 & 5.42 & 1.40 & 1.28 & 0.26 & 0.22 & 12.75 & 9.96 & 2.38 & 2.32 \\
\hline $\mathrm{T} 4$ & 5.43 & 5.22 & 1.34 & 1.37 & 0.24 & 0.24 & 10.62 & 8.98 & 2.36 & 2.30 \\
\hline T5 & 5.44 & 5.36 & 1.38 & 1.32 & 0.19 & 0.23 & 12.02 & 10.02 & 2.44 & 2.42 \\
\hline T6 & 5.46 & 5.18 & 1.32 & 1.30 & 0.29 & 0.26 & 13.92 & 11.06 & 2.41 & 2.36 \\
\hline $\mathrm{T} 7$ & 5.34 & 5.40 & 1.36 & 1.28 & 0.22 & 0.25 & $11 . .86$ & 10.34 & 2.48 & 2.32 \\
\hline $\mathrm{T} 8$ & 5.41 & 5.38 & 1.38 & 1.41 & 0.24 & 0.22 & 12.72 & 11.38 & 2.46 & 2.38 \\
\hline T9 & 5.38 & 5.44 & 1.42 & 1.38 & 0.26 & 0.24 & 12.88 & 12.2 & 2.42 & 2.33 \\
\hline Grand Mean & 5.41 & 5.33 & 1.37 & 1.33 & 0.23 & 0.22 & 12.12 & 10.52 & 2.40 & 2.33 \\
\hline
\end{tabular}

Where:

T1. Negative control (no input)

T2. $100 \%$ of recommended rate of $\mathrm{P}$ from NP source (positive control-1)

T3. $100 \%$ of recommended rate of $\mathrm{P}$ from $19 \mathrm{~N}-38 \mathrm{P}_{2} \mathrm{O}_{5}-7 \mathrm{~S}$ (positive control-2)

T4. $80 \%$ of recommended rate of $\mathrm{P}$ from $12 \mathrm{~N}-42 \mathrm{P}_{2} \mathrm{O}_{5}-10 \mathrm{~S}$

T5. $100 \%$ of recommended rate of $\mathrm{P}$ from $12 \mathrm{~N}-42 \mathrm{P}_{2} \mathrm{O}_{5}-10 \mathrm{~S}$

T6. $120 \%$ of recommended rate of $\mathrm{P}$ from $12 \mathrm{~N}-42 \mathrm{P}_{2} \mathrm{O}_{5}-10 \mathrm{~S}$

T7. $80 \%$ of recommended rate of $\mathrm{P}$ from $13.3 \mathrm{~N}-36 \mathrm{P}_{2} \mathrm{O}_{5}-13.7 \mathrm{~S}$

T8. $100 \%$ of recommended rate of $\mathrm{P}$ from $13.3 \mathrm{~N}-36 \mathrm{P}_{2} \mathrm{O}_{5}-13.7 \mathrm{~S}$ 
T9. $120 \%$ of recommended rate of $\mathrm{P}$ from $13.3 \mathrm{~N}-36 \mathrm{P}_{2} \mathrm{O}_{5}-13.7 \mathrm{~S}$

All the three parameters (plant height, grain yield and dry biomass) of faba bean were non-significantly $(\mathrm{P}>0.05)$ affected by different grade NPS fertilizer rates application in 2019, 2020 cropping seasons and combined over years (Table 5 and 6).

Table 5. Results of analysis of variance for faba bean, wheat and rape seed crops

\begin{tabular}{lccccccccc} 
& \multicolumn{9}{c}{ Faba Bean } \\
\cline { 2 - 10 } Source & \multicolumn{3}{c}{ Plant height $(\mathrm{cm})$} & \multicolumn{3}{c}{ Grain yield (kg/ha) } & \multicolumn{3}{c}{ Biomass yield (kg/ha) } \\
\cline { 2 - 11 } & DF & MS & P & DF & MS & P & DF & MS & P \\
nep & 2 & 27.105 & & 2 & 145748 & & 2 & 927511 & \\
Trt & 8 & 63.563 & 0.826 & 8 & 486326 & 0.1473 & 8 & 1779546 & 0.2274 \\
Error & 124 & 118.153 & & 124 & 314054 & & 124 & 1322765 & \\
\hline
\end{tabular}

Numerically, over years higher mean values (3038 and $6275 \mathrm{~kg} \mathrm{ha}^{-1}$ ) of grain and dry biomass yield of faba bean were obtained with application of $80 \%$ recommended rate of $\mathrm{P}$ from $13.3 \mathrm{~N}-36 \mathrm{P}_{2} \mathrm{O}_{5}-13.7 \mathrm{~S}$ as compared to other treatments (Table 6). The different grade NPS fertilizers and their rates evaluated in this experiment did not significantly affect the faba bean plant growth and yield parameters. Therefore, application of any of the different grade NPS fertilizers evaluated in this experiment can alternately be used considering the accessibility and cost of the fertilizer products to be incurred.

Table 6. Effects of differently graded NPS fertilizer on plant height, grain yield and dry biomass yield faba bean in 2019, 2020 and combined over years in Holeta

\begin{tabular}{|c|c|c|c|c|c|c|c|c|c|}
\hline \multirow[t]{2}{*}{ Treatments } & \multicolumn{3}{|c|}{ Plant height $(\mathrm{cm})$} & \multicolumn{3}{|c|}{ Grain yield $\left(\mathrm{kg} \mathrm{ha}^{-1}\right)$} & \multicolumn{3}{|c|}{ Dry biomass $\left(\mathrm{kg} \mathrm{ha}^{-1}\right)$} \\
\hline & 2019 & 2020 & Mean & 2019 & 2020 & mean & 2019 & 2020 & mean \\
\hline 1. Negative control ( 0 input $)$ & 131 & 130 & 131 & 2196 & 2742 & 2524 & 5882 & 4778 & 5219 \\
\hline 2. $100 \%$ of rec. rate of $\mathrm{P}$ from $\mathrm{NP}\left({ }^{+}\right.$ve cont'l- 1$)$ & 141 & 133 & 136 & 2833 & 2698 & 2752 & 7243 & 5185 & 6008 \\
\hline 3. $100 \%$ of rec. rate of $\mathrm{P}$ from $19 \mathrm{~N}-38 \mathrm{P}_{2} \mathrm{O}_{5}-7 \mathrm{~S}\left({ }^{+} v e\right.$ cont' 12$)$ & 139 & 133 & 135 & 2791 & 3087 & 2969 & 6965 & 5722 & 6219 \\
\hline 4. $80 \%$ of rec. rate of $\mathrm{P}$ from $12 \mathrm{~N}-42 \mathrm{P}_{2} \mathrm{O}_{5}-10 \mathrm{~S}$ & 139 & 128 & 133 & 2481 & 2875 & 2717 & 6201 & 4981 & 5469 \\
\hline 5. $100 \%$ of rec. rate of $\mathrm{P}$ from $12 \mathrm{~N}-42 \mathrm{P}_{2} \mathrm{O}_{5}-10 \mathrm{~S}$ & 136 & 134 & 135 & 2529 & 2482 & 2501 & 6814 & 5148 & 5814 \\
\hline 6. $120 \%$ of rec. rate of $\mathrm{P}$ from $12 \mathrm{~N}-42 \mathrm{P}_{2} \mathrm{O}_{5}-10 \mathrm{~S}$ & 137 & 131 & 133 & 2627 & 2725 & 2686 & 6861 & 5222 & 5878 \\
\hline 7. $80 \%$ of rec. rate of $\mathrm{P}$ from $13.3 \mathrm{~N}-36 \mathrm{P}_{2} \mathrm{O}_{5}-13.7 \mathrm{~S}$ & 141 & 130 & 134 & 2945 & 3100 & 3038 & 7215 & 5648 & 6275 \\
\hline 8. $100 \%$ of rec. rate of $\mathrm{P}$ from $13.3 \mathrm{~N}-36 \mathrm{P}_{2} \mathrm{O}_{5}-13.7 \mathrm{~S}$ & 135 & 132 & 133 & 2535 & 2831 & 2713 & 6369 & 5259 & 5703 \\
\hline 9. $120 \%$ of rec. rate of $\mathrm{P}$ from $13.3 \mathrm{~N}-36 \mathrm{P}_{2} \mathrm{O}_{5}-13.7 \mathrm{~S}$ & 139 & 137 & 137 & 2606 & 2647 & 2631 & 6403 & 5056 & 5594 \\
\hline LSD (5\%) & NS & NS & NS & NS & NS & NS & NS & NS & NS \\
\hline CV (\%) & 10.6 & 5.99 & 8.1 & 21.1 & 20.61 & 20.56 & 12.2 & 18.54 & 19.8 \\
\hline
\end{tabular}

NS=non-significant difference at 5\% probability level.

\section{Economic Aanalysis}

Although the statistical analysis of variance of yield was not significantly affected by the uses of different grade NPS fertilizer the results of the partial budget analysis of faba bean for different treatments are presented in Table 7. Higher net benefit of EB $63851.2 \mathrm{ha}^{-1}$ with the marginal rate of return of $4857.07 \%$ and value to cost ratio of EB 36.08 per unit of investment of faba bean was obtained with application of $80 \%$ of recommended rate of $\mathrm{P}$ from $13.3 \mathrm{~N}-36 \mathrm{P}_{2} \mathrm{O}_{5}-13.7 \mathrm{~S}$ fertilizer for faba bean. The second higher net benefit EB $62193.6 \mathrm{ha}^{-1}$ with marginal rate of return of $27493.2 \%$ and value to cost ratio of EB 32.11 per unit of investment of faba bean was obtained with application of $100 \%$ of recommended rate of $\mathrm{P}$ from $19 \mathrm{~N}-38 \mathrm{P}_{2} \mathrm{O}_{5}-7 \mathrm{~S}$ fertilizer rate or Positive control treatment. Therefore, the application of $36.8 \mathrm{~kg} \mathrm{P}_{2} \mathrm{O}_{5} \mathrm{Ha}^{-1}$ from $13.3 \mathrm{~N}_{-} 36 \mathrm{P}_{2} \mathrm{O}_{5}-13.7 \mathrm{~S}$ and $18 \mathrm{~kg} \mathrm{~N}^{-1}$ from both NPS and Urea fertilizers followed by NPS positive control or $46 \mathrm{~kg} \mathrm{P}_{2} \mathrm{O}_{5} \mathrm{Ha}^{-1}$ and $18 \mathrm{~kg} \mathrm{~N} \mathrm{ha}{ }^{-1}$ from $19 \mathrm{~N}-38 \mathrm{P}_{2} \mathrm{O}_{5}-7 \mathrm{~S}$ fertilizer was found to be economically sound for production of faba bean in Welmera and Ejere districts of central Ethiopia.

Table 7. Partial budget analysis for evaluation of different grade NPS fertilizers effect on performance of faba bean.

\begin{tabular}{|c|c|c|c|c|c|c|c|c|c|}
\hline Treatments & $\begin{array}{l}\text { NPS } \\
\text { Ct. }\end{array}$ & Urea Ct. & Grain yield $\left(\mathrm{kg} \mathrm{ha}^{-1}\right)$ & Adjusted grain yield $\left(\mathrm{kg} \mathrm{ha}^{-1}\right)$ & $\begin{array}{l}\text { Gross field benefit } \\
\left(\mathrm{EB} \mathrm{ha}^{-1}\right)\end{array}$ & $\begin{array}{l}\text { TVC } \\
\left(\mathrm{EB} \mathrm{ha}^{-1}\right)\end{array}$ & $\begin{array}{l}\text { Net benefit } \\
\left(\text { EB ha }{ }^{-1}\right)\end{array}$ & Value to cost ratio & $\begin{array}{l}\text { MRR } \\
(\%)\end{array}$ \\
\hline $\mathrm{T} 1$ & 0.0 & 0.0 & 2524 & 2271.6 & 54518.4 & 0.0 & 54518.4 & & \\
\hline $\mathrm{T} 2$ & 1600.0 & 0.0 & 2752 & 2476.8 & 59443.2 & 1600.0 & 57843.2 & 36.15 & 207.8 \\
\hline T4 & 1401.9 & 227.8 & 2717 & 2445.3 & 58687.2 & 1629.7 & 57057.5 & 35.01 & $\mathrm{D}$ \\
\hline $\mathrm{T} 7$ & 1635.6 & 134.0 & 3038 & 2734.2 & 65620.8 & 1769.6 & 63851.2 & 36.08 & 4857.07 \\
\hline T5 & 1752.4 & 147.8 & 2501 & 2250.9 & 54021.6 & 1900.2 & 52121.4 & 27.43 & $\mathrm{D}$ \\
\hline T3 & 1936.8 & 0.0 & 2969 & 2672.1 & 64130.4 & 1936.8 & 62193.6 & 32.11 & 27493.2 \\
\hline $\mathrm{T} 8$ & 2044.4 & 30.6 & 2713 & 2441.7 & 58600.8 & 2075.0 & 56525.8 & 27.24 & $\mathrm{D}$ \\
\hline T6 & 2102.9 & 67.8 & 2686 & 2417.4 & 58017.6 & 2170.7 & 55846.9 & 25.73 & $\mathrm{D}$ \\
\hline T9 & 2453.3 & 0.0 & 2631 & 2367.9 & 56829.6 & 2453.3 & 54376.3 & 22.16 & $\mathrm{D}$ \\
\hline
\end{tabular}

\section{Conclusions}

Based on the agronomically optimum yield performance and economic benefits obtained from the application of different grade NPS fertilizer rates, the following conclusion can be made. 
- For faba bean production, the different grade NPS fertilizers and their rates evaluated did not significantly affect growth and yield parameters of the crop when compared to an already existing P source fertilizer recommendation rate. Therefore, unless there exist special comparative advantage of better on market availability and market price of the different grade NPS fertilizers, the previously used P source fertilizer (DAP) is more promising to use in the study locations.

- As the partial budget analysis result was indicated economically the highest net benefit and marginal rate of return was obtained from $80 \%$ of rec. rate of $\mathrm{P}$ from $13.3 \mathrm{~N}-36 \mathrm{P}_{2} \mathrm{O}_{5}-13.7 \mathrm{~S}$ followed by conventional NPS grade fertilizer applied by recommended rate for faba bean in the previous studies.

- Base on the study result of this experiment, further evaluation or validation of the promising treatments on relatively larger plots in similar agro ecological zones but also out of the current study areas is of paramount important to increase the level of confidence for their wider applicability.

\section{References}

Bray, H.R. and Kurtz, L.T. 1945. Determination of organic and available forms of phosphorus in soils. Soil Science 9:39-46.

Bremner, J.M. and Mulvaney, C.S. 1982. Nitrogen-total. In: Methods of Soil Analysis (Edited by Page A.L, Miller R.H. and Keeney D.R.), part 2, chemical and microbiological properties. $2^{\text {nd }}$ edition, Madison, WI: American Society of Agronomy. pp. 595-624.

Chesnin, L. and Yien, C.H. 1951. Turbidimetric Determination of Available Sulphur. Proceedings of Soil Science Society of America. 15: 149-151.

CIMMYT, 1988: From agronomic data to farmer recommendations: an economics training manual (completely revised edition). CIMMYT, Mexico, DF, pp 9-38.

CSA (Central statistical agency). 2018. Report on area and production of major crops for 2010 EC (private peasant holdings, Meher Season). Statistical Bulletin Volume 1. No. 586. Addis Ababa, Ethiopia

Dewis, J. and Freitas, F. 1984. Physical and Chemical Methods of Soil and Water Analysis. FAO Soil Bulletin No. 10. FAO, Rome. $275 \mathrm{pp}$

Ethiosis (Ethiopia Soil Information System). 2014. Soil analysis report. Agricultural Transformation Agency (Unpublished).

Gete Zeleke, Getachew Agegnehu, Dejene Abera and Rashid S. 2010. Fertilizer and soil fertility potential in Ethiopia: Constraints and opportunities for enhancing the system. International Food Policy Research Institute (IFPRI), pp. 63, Washington, DC, USA.

McLean, E.O. 1965. Aluminum. In: Methods of Soil Analysis (Edited by Black, C.A.), Agronomy No. 9. Part II. American Society of Agronomy Madison, Wisconsin. USA. pp. 978-998.

Mclean, E.O. 1982. Soil pH and Lime Requirement. In: Methods of Soil Analysis (Edited by Page A.L, Miller R.H. and Keeney D.R.), Part 2 chemical and microbiological properties. $2^{\text {nd }}$ edition, American Society of Agronomy, Madison, 101. USA. pp. 199-234.

Nelson, D.W. and Sommers, L.E. 1982. Total Carbon, Organic Carbon and Organic Matter. In: Methods of soil analysis. (Edited by Page A.L, Miller R.H. and Keeney D.R.), Part 2. Chemical and Microbiological properties. $2^{\text {nd }}$ edition, America Society Agronomy, Madison. WI. USA. pp. 359-580.

SAS (Statistical Analysis System) Institute, 2012. The SAS system for windows, version 8.1, Vol.1. SAS Institute Inc. Cary NC., USA.

Tekalign Tadesse. 1991. Soil, plant, fertilizer, animal manure and compost analysis manual. International Livestock center for Africa, No. B13. Addis Ababa, Ethiopia.

Walkley, A. 1947. An examination of Degtjareff method for determining soil organic matter and the proposed modification of the chromic acid titration method. Soil Science 37: 29-38.

Lindsay C. Campbell. 1998. Managing Soil Fertility Decline, Journal of Crop Production, 1:2, 29-52 